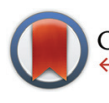

CrossMark $\leftarrow$ click for updates

Cite this: Dalton Trans., 2015, 44 1592

Received 15th September 2014, Accepted 15th November 2014 DOI: $10.1039 / c 4 d t 02819 \mathrm{~h}$ www.rsc.org/dalton

\section{Structural complexity in indium selenides prepared using bicyclic amines as structure-directing agents $\uparrow$}

\author{
S. J. Ewing ${ }^{a}$ and P. Vaqueiro ${ }^{a, b}$
}

The synthesis and characterization of five new indium selenides, $\left[\mathrm{C}_{9} \mathrm{H}_{17} \mathrm{~N}_{2}\right]_{3}\left[\mathrm{ln}_{5} \mathrm{Se}_{8+x}\left(\mathrm{Se}_{2}\right)_{1-x}\right]$ (1-2), $\left[\mathrm{C}_{6} \mathrm{H}_{12} \mathrm{~N}_{2}\right]_{4}\left[\mathrm{C}_{6} \mathrm{H}_{14} \mathrm{~N}_{2}\right]_{3}\left[\mathrm{In}_{10} \mathrm{Se}_{15}\left(\mathrm{Se}_{2}\right)_{3}\right](3),\left[\mathrm{C}_{6} \mathrm{H}_{14} \mathrm{~N}_{2}\right]\left[\left(\mathrm{C}_{6} \mathrm{H}_{12} \mathrm{~N}_{2}\right)_{2} \mathrm{Naln}_{5} \mathrm{Se}_{9}\right]$ (4) and $\left[\mathrm{enH}_{2}\right]\left[\mathrm{NH}_{4}\right]\left[\mathrm{In}_{7} \mathrm{Se}_{12}\right](5)$, are described. These materials were prepared under solvothermal conditions, using 1,8-diazabicyclo[5.4.0]undec-7-ene (DBU) and 1,4-diazabicyclo[2.2.2]octane (DABCO) as structure-directing agents. Compounds $\mathbf{1 - 4}$ represent the first examples of ribbons in indium selenides, and $\mathbf{4}$ is the first example of incorporation of an alkali metal complex. Compounds 1, 2 and 4 contain closely related $\left[\ln _{5} \mathrm{Se}_{8+x}\left(\mathrm{Se}_{2}\right)_{1-x}\right]^{3-}$ ribbons which differ only in their content of $\left(\mathrm{Se}_{2}\right)^{2-}$ anions. These ribbons are interspaced by organic countercations in $\mathbf{1}$ and $\mathbf{2}$, while in $\mathbf{4}$ they are linked by highly unusual $\left[\mathrm{Na}(\mathrm{DABCO})_{2}\right]^{+}$units into a threedimensional framework. Compound 3 contains complex ribbons, with a long repeating sequence of $c a$. $36 \AA$, and 4 is a non-centrosymmetric three-dimensional framework, formed as a consequence of the decomposition of DABCO into ethylenediamine (en) and ammonia.

\section{Introduction}

Open-framework chalcogenides are of considerable interest due to their potential as multifunctional materials in which semiconductivity and porosity coexist, and have already shown promising behavior as photocatalysts, ${ }^{1}$ fast-ion conductors ${ }^{2}$ and for the selective ion exchange of heavy metals. ${ }^{3}$ Moreover, the primary building units in many of these chalcogenides lack an inversion centre, and hence are ideal building blocks for non-centrosymmetric solids, which may find applications in second-order nonlinear optics. ${ }^{4}$ Significant progress has already been made in the synthesis of open-framework indium sulfides, which are frequently built from supertetrahedral clusters. ${ }^{5}$ In comparison with indium sulfides, few examples are known of the corresponding selenides.

With the exception of $\left[\mathrm{C}_{7} \mathrm{H}_{10} \mathrm{~N}\right]\left[\mathrm{In}_{3} \mathrm{Se}_{5}\right],{ }^{6}$ which contains octahedrally coordinated indium, the primary building unit found to date in the limited number of solvothermallyprepared indium selenides is the $\mathrm{InSe}_{4}{ }^{5-}$ tetrahedron. Vertex linkage of these tetrahedra can result in the formation of

\footnotetext{
${ }^{a}$ Institute of Chemical Sciences, Heriot Watt University, Edinburgh, EH14 4AS, UK ${ }^{b}$ Department of Chemistry, University of Reading, Whiteknights, Reading RG6 6AD, UK. E-mail: p.vaqueiro@reading.ac.uk

$\dagger$ Electronic supplementary information (ESI) available: Local coordination diagrams, and powder X-ray diffraction patterns, thermogravimetric and FT-IR data for 1-5. CCDC 1023692-1023696. For ESI and crystallographic data in CIF or other electronic format see DOI: 10.1039/c4dt02819h
}

supertetrahedral clusters, but very few indium selenides contain supertetrahedral clusters as secondary building units. This includes three-dimensional frameworks with the doubleand single-diamond topologies, ${ }^{2,7}$ and $\left[\mathrm{NH}_{4}\right]\left[\mathrm{InSe}_{2}\right]$, which is a non-centrosymmetric material with nonlinear optical behaviour. ${ }^{8}$ Vertex-linking of $\mathrm{InSe}_{4}{ }^{5-}$ tetrahedra can lead to other secondary building units, such as the nonanuclear indium clusters found in the microporous structure of $\left[\mathrm{NH}_{4}\right]_{4}\left[\mathrm{In}_{12} \mathrm{Se}_{20}\right], 3$ or to the helical chains found in the $\left[\mathrm{In}_{33} \mathrm{Se}_{56}\right]^{13-}$ open framework. ${ }^{9}$ Edge-sharing of InSe ${ }_{4}{ }^{5-}$ tetrahedra is also possible, as exemplified by $\left[\mathrm{C}_{7} \mathrm{H}_{10} \mathrm{~N}\right]\left[\mathrm{In}_{9} \mathrm{Se}_{14}\right]$, in which edge- and vertex-sharing tetrahedra coexist. ${ }^{10}$ When InSe $_{4}{ }^{5-}$ tetrahedra are linked exclusively by their edges, $\left[\mathrm{InSe}_{2}\right]^{-}$chains are obtained. These have been found in a polymorphic form of $\left[\mathrm{NH}_{4}\right]\left[\mathrm{InSe}_{2}\right]^{8}$ and in $[$ bdah $]\left[\mathrm{InSe}_{2}\right]$ (where bda = 1,4-butanediamine). ${ }^{11}$ Recently, it has been found that replacement of $\mathrm{Se}^{2-}$ with perselenide $\left(\mathrm{Se}_{2}\right)^{2-}$ anions in the $\left[\mathrm{InSe}_{2}\right]^{-}$ chains can occur, resulting in the formation of chains in which four and five-membered rings alternate, as exemplified by $\left[\mathrm{C}_{6} \mathrm{H}_{16} \mathrm{~N}_{2}\right]\left[\mathrm{In}_{2} \mathrm{Se}_{3}\left(\mathrm{Se}_{2}\right)\right],\left\{\left[\mathrm{M}(\text { phen })_{3}\right] \mathrm{In}_{2} \mathrm{Se}_{5} \cdot \mathrm{H}_{2} \mathrm{O}\right\}_{n}$ (where $\mathrm{M}=$ $\mathrm{Ni}$, Fe; phen $=1,10$-phenanthroline) and $\left[\mathrm{Mn}(\mathrm{en})_{3}\right]\left[\mathrm{In}_{2} \mathrm{Se}_{5}\right] .{ }^{12}$

Despite the ongoing research efforts on the solvothermal synthesis of new indium selenides, the number of reported phases has remained low. This may be related to the low selectivity with which a particular structure is crystallised with a specific structure-directing agent. For instance, we have found that frameworks such as $\left[\mathrm{NH}_{4}\right]\left[\mathrm{In}_{12} \mathrm{Se}_{20}\right]$ or $\left[\mathrm{In}_{33} \mathrm{Se}_{56}\right]^{13-}$ can be obtained using a wide variety of structure-directing 
agents. In an effort to identify structure-directing agents with selectivity towards novel selenides, we have explored the use of organic superbases, and in particular, of two distinctly different bicyclic amines, 1,8-diazabicyclo[5.4.0]undec-7-ene (DBU) and 1,4-diazabicyclo[2.2.2] octane (DABCO). This work, which is described here, has resulted in the synthesis and characterisation of five new indium selenides (1-5) of varying dimensionality, which exhibit a number of novel structural features, including the incorporation of $\left(\mathrm{Se}_{2}\right)^{2-}$ anions and of highly unusual $\left[\mathrm{Na}(\mathrm{DABCO})_{2}\right]^{+}$units.

\section{Experimental}

\section{Materials and methods}

Syntheses were carried out using $23 \mathrm{~mL}$ Teflon lined stainless steel autoclaves. The reagents were added individually to the Teflon liner and mixed for approximately 10 minutes, prior to sealing the reaction vessel. The sealed autoclaves were then heated to a set temperature for a defined period of time. After cooling to room temperature, the products were collected by vacuum filtration and washed with deionised water, methylated spirits and acetone.

Synthesis of $\left[\mathrm{C}_{9} \mathrm{H}_{17} \mathrm{~N}_{2}\right]_{3}\left[\mathrm{In}_{5} \mathrm{Se}_{\mathbf{8 . 0 7}}\left(\mathrm{Se}_{2}\right)_{0.93}\right]$ (1). A mixture of In $(0.1676 \mathrm{~g}, 1.46 \mathrm{mmol}, 99+\%$, Aldrich), Se powder $(0.2369 \mathrm{~g}$, $3 \mathrm{mmol}$, 99.99\%, Alfa Aesar), DBU (0.3 mL, $2.01 \mathrm{mmol}, 98 \%$ ), imidazole $(0.2042 \mathrm{~g}, 3 \mathrm{mmol}, \geq 99 \%)$ and acetonitrile $(3 \mathrm{~mL}$, Fisher) was placed in a sealed autoclave. The vessel was heated to $200{ }^{\circ} \mathrm{C}$ for 10 days. The product contained a small amount of a black powder and large yellow crystals. The yellow crystals were identified as $\mathbf{1}$ by single crystal X-ray diffraction. Elemental analysis: found: $\mathrm{C}=17.55 \%, \mathrm{H}=2.69 \%, \mathrm{~N}=4.38 \%$; calc.: $\mathrm{C}=17.84 \%, \mathrm{H}=2.83 \%, \mathrm{~N}=4.62 \%$.

Synthesis of $\left[\mathrm{C}_{9} \mathbf{H}_{17} \mathbf{N}_{2}\right]_{3}\left[\operatorname{In}_{5} \mathrm{Se}_{8.74}\left(\mathrm{Se}_{2}\right)_{0.26}\right]$ (2). This compound was synthesised using $\operatorname{InCl}_{3}(0.3229 \mathrm{~g}, 1.46 \mathrm{mmol}, 98 \%$, Aldrich) with Se powder (0.2369 g, $3 \mathrm{mmol}$, 99.99\%, Alfa Aesar) and DBU (1 mL, $6.7 \mathrm{mmol}, 98 \%$, Aldrich). The sealed vessel was heated at $200{ }^{\circ} \mathrm{C}$ for 10 days. The collected product consisted of yellow rod-like crystals of 2 . Elemental analysis: found: $\mathrm{C}=18.39 \%, \mathrm{H}=2.95 \%, \mathrm{~N}=4.67 \%$; calc.: $\mathrm{C}=18.37 \%$, $\mathrm{H}=2.91 \%, \mathrm{~N}=4.76 \%$.

Synthesis of $\left[\mathrm{C}_{6} \mathrm{H}_{12} \mathbf{N}_{2}\right]_{4}\left[\mathrm{C}_{6} \mathbf{H}_{14} \mathbf{N}_{2}\right]_{3}\left[\operatorname{In}_{10} \mathrm{Se}_{15}\left(\mathrm{Se}_{2}\right)_{3}\right]$ (3). A mixture of In (0.1676 g, $1.46 \mathrm{mmol}, 99.99 \%$, Aldrich), Se powder (0.2369 g, $3 \mathrm{mmol}$, 99.99\%, Alfa Aesar), DABCO (0.6731 g, $6 \mathrm{mmol}, \geq 99 \%$, Aldrich) and dimethylformamide (DMF, $6 \mathrm{~mL}$, Fisher), with the approximate molar composition $1.5: 3: 6: 78$, was placed in a Teflon liner, sealed and heated at $140{ }^{\circ} \mathrm{C}$ for 10 days. The product contained an abundance of small brown crystals, which were identified as 3 by singlecrystal diffraction, and a small amount of orange powder. Elemental analysis: found: $\mathrm{C}=11.51 \%, \mathrm{H}=1.90 \%, \mathrm{~N}=4.25 \%$; calc.: $\mathrm{C}=14.02 \%, \mathrm{H}=2.52 \%, \mathrm{~N}=5.45 \%$.

Synthesis of $\left[\mathrm{C}_{6} \mathrm{H}_{14} \mathbf{N}_{2}\right]\left[\left(\mathrm{C}_{6} \mathrm{H}_{12} \mathbf{N}_{2}\right)_{2} \mathrm{NaIn}_{5} \mathrm{Se}_{9}\right]$ (4). This compound was prepared using In $(0.1676 \mathrm{~g}, 1.46 \mathrm{mmol}, 99.99 \%$, Alfa Aesar), Se (0.2369 g, 3 mmol, 99.9\%, Alfa Aesar), DABCO (0.6731 g, $6 \mathrm{mmol}, \geq 99 \%$, Aldrich), $0.1 \mathrm{~mL}$ of $15 \mathrm{wt} \% \mathrm{NaOH}$ solution and $6 \mathrm{~mL}$ of acetonitrile, loaded into a Teflon-lined stainless steel autoclave with the approximate molar composition of $1.46: 3: 6: 0.4: 115$. The reaction was carried out at $140{ }^{\circ} \mathrm{C}$ for 10 days. The product consisted of a small amount of black powder with an abundance of brown prism crystals of 4. Smaller yields of 4 were obtained when $1 \mathrm{mmol}$ of a sodium source such as $\mathrm{Na}\left(\mathrm{NO}_{3}\right), \mathrm{Na}\left(\mathrm{COOCH}_{3}\right), \mathrm{Na}_{2}\left(\mathrm{C}_{2} \mathrm{O}_{4}\right)$ or $\mathrm{Na}_{2}\left(\mathrm{CO}_{3}\right)$ were added to the reaction, instead of $\mathrm{NaOH}$. Elemental analysis: found: $\mathrm{C}=12.91 \%, \mathrm{H}=2.20 \%, \mathrm{~N}=4.67 \%$; calc.: $\mathrm{C}=$ $13.12 \%, \mathrm{H}=2.33 \%, \mathrm{~N}=5.10 \%$.

Synthesis of $\left[\mathrm{enH}_{2}\right]\left[\mathrm{NH}_{4}\right]\left[\mathrm{In}_{7} \mathrm{Se}_{12}\right]$ (5). This material was prepared using In powder (0.1676 g, $1.46 \mathrm{mmol}$, 99.99\%, Aldrich), Se powder (0.2369 g, $3 \mathrm{mmol}$, 99.99\%, Alfa Aesar), DABCO (0.6731 g, $6 \mathrm{mmol}, \geq 99 \%$, Aldrich) and deionised water (3 mL), heated to $200{ }^{\circ} \mathrm{C}$ for 14 days. The resulting product contained numerous yellow plates of 5 , and a small amount of red needle-like crystals identified by single-crystal X-ray diffraction as the previously reported $\left.\left[\mathrm{NH}_{4}\right]_{4}\left[\mathrm{In}_{12} \mathrm{Se}_{20}\right]\right]^{3}$ The presence of ammonium and ethylenediamine cations in the crystal structure of 5 suggested that DABCO decomposed under solvothermal conditions. A similar decomposition of DABCO has been reported in the hydrothermal preparation of uranium fluorides. ${ }^{13}$ Attempts were made to prepare 5 from the products of the decomposition of DABCO. For this purpose, ethylenediamine dihydrochloride (3 mmol, 99\%, Aldrich) and ammonium chloride (3 mmol, 99.9\%, Aldrich) were used, together with In powder $(1.46 \mathrm{mmol})$, Se $(3 \mathrm{mmol})$ and deionised water $(3 \mathrm{~mL})$ at $200{ }^{\circ} \mathrm{C}$ for 10 days. This reaction gave a brownish powder where $\mathbf{5}$ was identified by powder X-ray diffraction, but no single crystals were observed. Elemental analysis for 5: found: $\mathrm{C}=1.22 \%, \mathrm{H}=0.88 \%, \mathrm{~N}=2.29 \%$; calc.: $\mathrm{C}=$ $1.31 \%, \mathrm{H}=0.77 \%, \mathrm{~N}=2.29 \%$.

\section{Single-crystal diffraction}

Single-crystal X-ray diffraction data for crystals of 1-4 were collected at $100 \mathrm{~K}$, whilst data for $\mathbf{5}$ were collected at 293 K. For 3, the crystal used for data collection was particularly small, despite unsuccessful attempts to optimize the reaction conditions to grow larger crystals. The structures of 1-4 were solved using the charge-flipping method, Superflip, ${ }^{14}$ while that of 5 was solved using SHELX, ${ }^{15}$ which located the In and Se atoms. Organic molecules were generally found in the difference Fourier maps. Subsequent Fourier calculations and least squares refinements on $\mathrm{F}$ were carried out using the CRYSTALS program ${ }^{16}$ for all structures. Hydrogens were not placed on the ammonium cation in $\mathbf{5}$ as they are likely to be disordered. Selected crystallographic information for these compounds is shown in Table 1. Data have been deposited with the Cambridge Crystallographic Data Centre as CCDC 1023692-1023696.

\section{Characterisation}

Powder X-ray diffraction data were collected using a Bruker D8 Advance powder diffractometer, operating with germanium monochromated $\mathrm{CuK}_{\alpha 1}$ radiation $(\lambda=1.5406 \AA)$ fitted with a Bruker LynxEye linear detector. Data were collected, on a 
Table 1 Crystallographic data for compounds 1-5

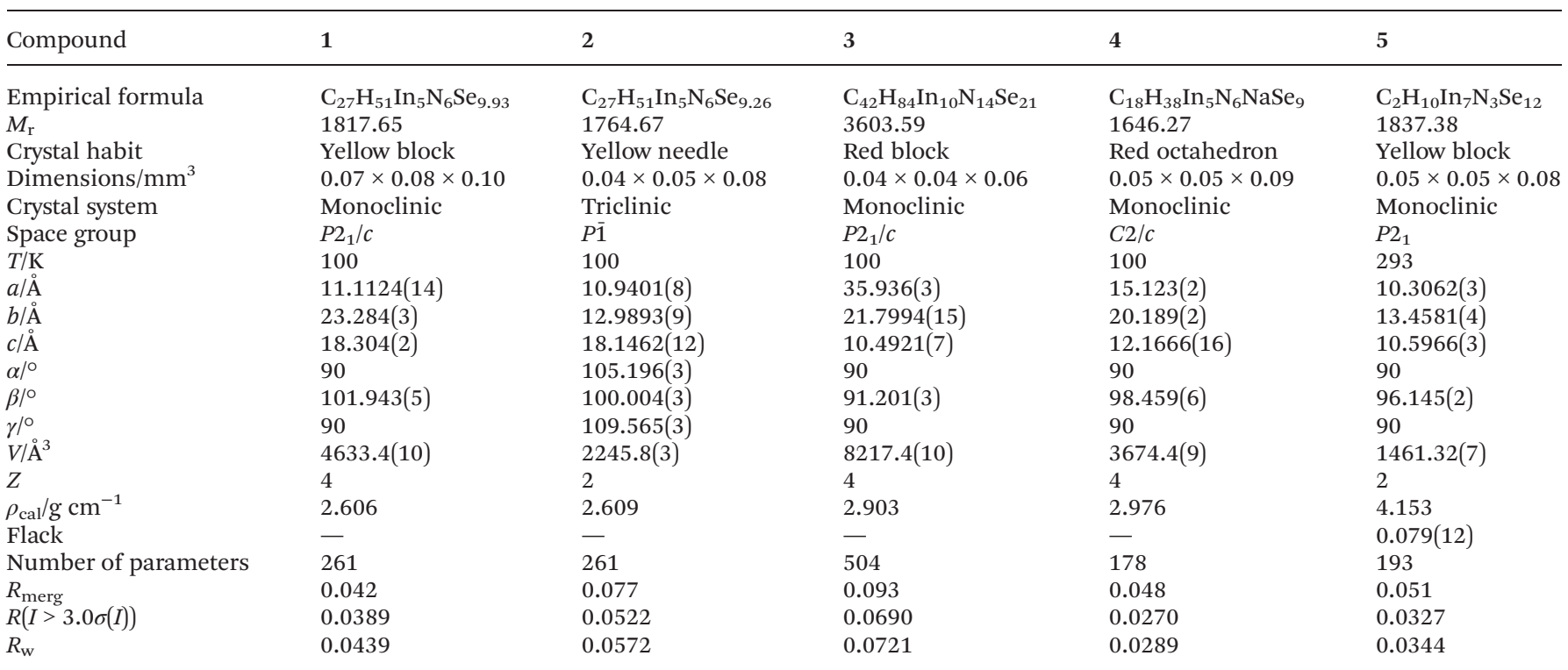

ground portion of the reaction product, over the angular range $5 \leq 2 \theta /{ }^{\circ} \leq 85$ with a step size of $0.009^{\circ}$. Lattice parameters were determined using Topas. ${ }^{17}$ Analysis of powder X-ray diffraction data (ESI) indicates that 1-5 are the main products obtained. Elemental analysis on handpicked crystals was carried out on an Exeter CE-440 elemental analyser. Thermogravimetric analysis was performed using a DuPont Instruments 951 thermal analyser. Approximately $10 \mathrm{mg}$ of finely ground crystals were heated under a flow of $\mathrm{O}_{2}$ over the temperature range $30 \leq T /{ }^{\circ} \mathrm{C} \leq 1000$. Diffuse reflectance measurements were performed using a Perkin Elmer Lambda 35 UV-vis spectrometer. $\mathrm{BaSO}_{4}$ powder was used as a reference $(100 \%$ reflectance) and absorption data were calculated from the Kubelka-Munk function. ${ }^{18}$ Infrared measurements were carried out using a Perkin Elmer Spectrum 100 ATR spectrometer.

\section{Results}

\section{Crystal structures of 1 and 2}

Although 1 crystallises in the monoclinic space group $P 2_{1} / c$, whilst 2 is triclinic $(P \overline{1})$, their crystal structures are closely related, and consist of anionic ribbons separated by protonated DBU cations. The ribbons found in $\mathbf{1}$ and $\mathbf{2}$ have the compositions $\left[\operatorname{In}_{5} \mathrm{Se}_{8.07}\left(\mathrm{Se}_{2}\right)_{0.93}\right]^{3-}$ and $\left[\mathrm{In}_{5} \mathrm{Se}_{8.74}\left(\mathrm{Se}_{2}\right)_{0.26}\right]^{3-}$ respectively, and differ only in the content and arrangement of disordered $\left(\mathrm{Se}_{2}\right)^{2-}$ units. The simplest fragment of the anionic ribbon in $\mathbf{1}$ is shown in Fig. 1(a). This repeating unit contains five crystallographically-independent tetrahedra linked by their edges and corners. In this unit, three tetrahedra containing $\operatorname{In}(1), \operatorname{In}(4)$ and $\operatorname{In}(5)$ are linked by their corners forming a sixmembered ring. The $\mathrm{In}(5) \mathrm{Se}_{4}$ tetrahedron is linked by an edge to an $\operatorname{In}(3) \mathrm{Se}_{4}$ tetrahedron, forming a four-membered ring. The linkage between $\operatorname{In}(4) \mathrm{Se}_{4}$ and $\operatorname{In}(2) \mathrm{Se}_{4}$ is more complex, (a)

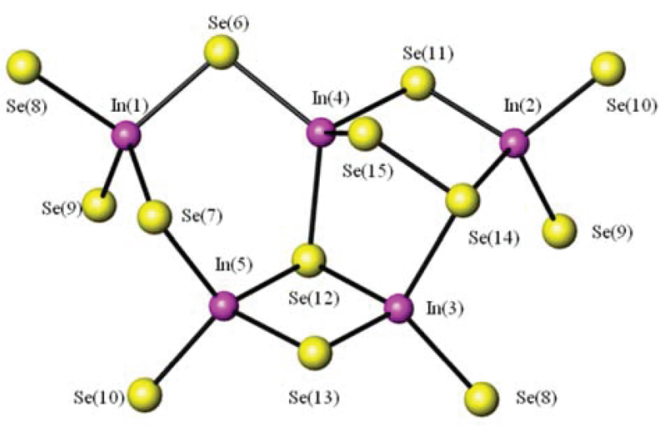

(b)

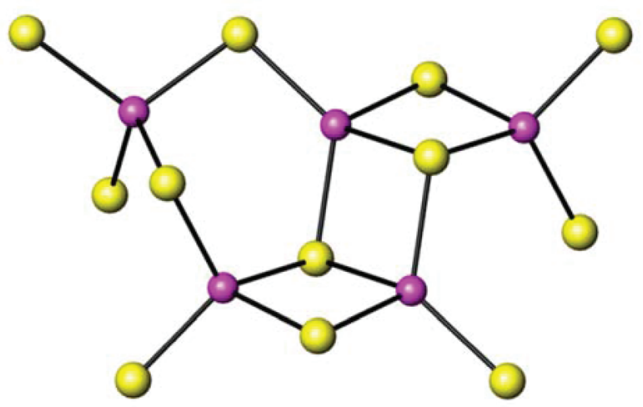

Fig. 1 View of the building block for the $\left[\ln _{5} \mathrm{Se}_{8+x}\left(\mathrm{Se}_{2}\right)_{1-x}\right]^{3-}$ ribbons in (a) compound 1, and (b) compound 2. For clarity, the disordered $\mathrm{Se}^{2-}$ in 1 , and the disordered $\left(\mathrm{Se}_{2}\right)^{2-}$ in 2 , have been omitted. Key: indium, large pink circles; selenium, large yellow circles.

due to the coexistence of disordered $\left(\mathrm{Se}_{2}\right)^{2-}$ and $\mathrm{Se}^{2-}$ moieties. Depending on whether a $\mathrm{Se}^{2-}$ or a $\left(\mathrm{Se}_{2}\right)^{2-}$ unit is present, the linkage between $\operatorname{In}(4) \mathrm{Se}_{4}$ and $\operatorname{In}(2) \mathrm{Se}_{4}$ creates a four- or a fivemembered ring. In 1, the perselenide linkage shown in Fig. 1(a) is dominant, with the fractional occupancy of the $\left(\mathrm{Se}_{2}\right)^{2-}$ unit being $92.66(18) \%$, whilst the occupancy of the corresponding 
(a)

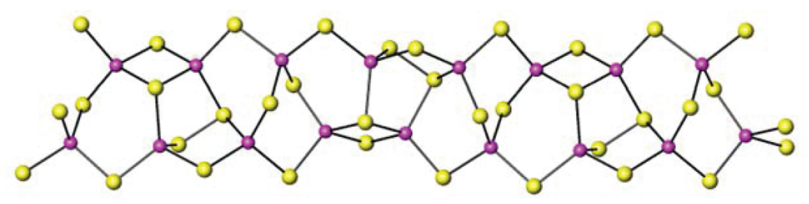

(b)

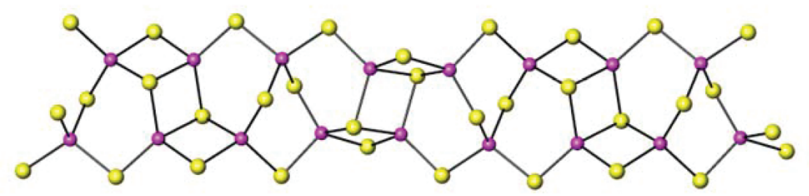

Fig. 2 Anionic $\left[\ln _{5} \mathrm{Se}_{8+x}\left(\mathrm{Se}_{2}\right)_{1-x}\right]^{3-}$ ribbons found in 1, 2 and 4. (a) Ribbon found in $1(x=0.93)$, showing the predominant five-membered perselenide rings. (b) Ribbon found in $2(x=0.26)$ and $4(x=0)$, showing the predominant four-membered rings. Key as for Fig. 1.

$\mathrm{Se}^{2-}$ is only $7.34(18) \%$. By contrast, in 2 (Fig. 1(b)) fourmembered rings are predominant, as reflected by a fractional occupancy for the perselenide $\left(\mathrm{Se}_{2}\right)^{2-}$ moiety of $25.6(2) \%$, whilst the single $\mathrm{Se}^{2-}$ has an occupancy of $74.4(2) \%$. Compounds 1 and 2 also differ in the location of the perselenide moiety within the repeating unit. In $1, \operatorname{In}(5) \mathrm{Se}_{4}$ and $\operatorname{In}(3)$ $\mathrm{Se}_{4}$ always form a four-membered ring, while the ring formed by $\operatorname{In}(2) \mathrm{Se}_{4}$ and $\operatorname{In}(4) \mathrm{Se}_{4}$ can be a four- or a five-membered ring. By contrast, in 2 partial replacement of a $\mathrm{Se}^{2-}$ by a $\left(\mathrm{Se}_{2}\right)^{2-}$ can occur in both four-membered rings. The Se-Se distance in the perselenide is 2.379(11) $\AA$ for 1 and 2.356(7) for 2, similar to the values previously reported for indium selenides containing $\left(\mathrm{Se}_{2}\right)^{2-}$ moieties. $^{12}$

In 1, each $\left[\operatorname{In}_{5} \operatorname{Se}_{11+x}\left(\mathrm{Se}_{2}\right)_{1-x}\right]^{9-}$ repeating unit is linked to two other $\left[\operatorname{In}_{5} \mathrm{Se}_{11+x}\left(\mathrm{Se}_{2}\right)_{1-x}\right]^{9-}$ blocks, which are rotated by $180^{\circ}$, via the terminal Se (8), $\operatorname{Se}(9)$ and $\operatorname{Se}(10)$ atoms, forming the one-dimensional ribbon shown in Fig. 2(a). Compound 2 (Fig. 2(b)) differs from 1 in the distribution of perselenide moieties along the ribbon. In $2,\left[\operatorname{In}_{5} \mathrm{Se}_{12}\right]^{9-}$ units, which contain no $\left(\mathrm{Se}_{2}\right)^{2-}$, alternate with $\left[\operatorname{In}_{5} \mathrm{Se}_{10+2 x}\left(\mathrm{Se}_{2}\right)_{2-2 x}\right]^{9-}$ units. In both cases, the overall stoichiometry of the ribbon is given by the general formula $\left[\operatorname{In}_{5} \mathrm{Se}_{8+x}\left(\mathrm{Se}_{2}\right)_{1-x}\right]^{3-}$. Charge balance is achieved through the incorporation of protonated organic amines into the crystal structure. As shown in Fig. 3, the ribbons in $\mathbf{1}$ and $\mathbf{2}$ are aligned parallel to the $c$-axis, and separated by the protonated organic cations.

\section{Crystal structure of 3}

Compound 3 crystallises in the monoclinic space group $P 2_{1} / c$ and contains a complex one-dimensional ribbon with stoichiometry $\left[\operatorname{In}_{10} \mathrm{Se}_{15}\left(\mathrm{Se}_{2}\right)_{3}\right]^{6-}$. The asymmetric unit of 3 (ESI) has ten crystallographically-independent indium atoms, all of which are tetrahedrally coordinated to selenium atoms. The $\mathrm{InSe}_{4}$ tetrahedra are linked via vertex- and edge-sharing. This creates a number of six-[ $\left[\operatorname{In}_{3} \mathrm{Se}_{3}\right]$, five-[ $\left[\mathrm{In}_{2} \mathrm{Se}_{3}\right]$ and four-[ $\left.\operatorname{In}_{2} \mathrm{Se}_{2}\right]$ membered rings, which were also present in $\mathbf{1}$ and $\mathbf{2}$, as well as $\left[\mathrm{In}_{2} \mathrm{Se}_{4}\right]$ and $\left[\mathrm{In}_{4} \mathrm{Se}_{4}\right]$ rings, not found in $\mathbf{1}$ and 2 . The Se-Se distances in the perselenide $\left(\mathrm{Se}_{2}\right)^{2-}$ units present in this material (a)

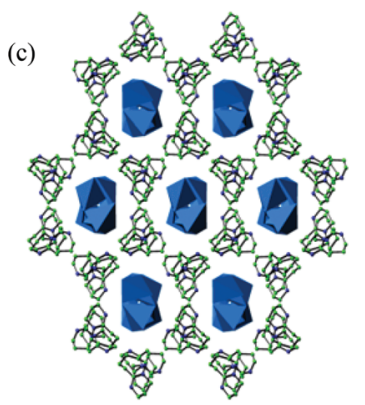

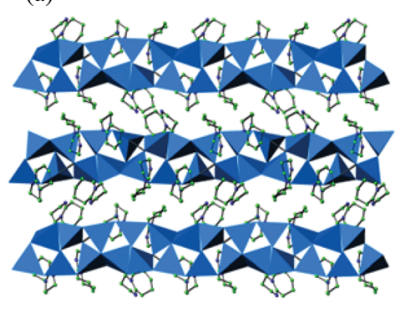

(b)

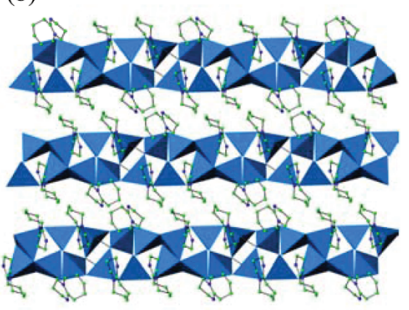

(d)

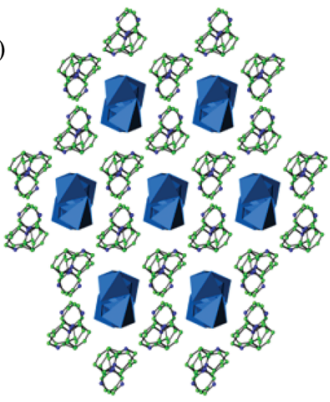

Fig. 3 Polyhedral representation of the crystal structures of 1 and 2 , viewed along [100] for (a) 1 and (b) 2, and along [001] for (c) 1 and (d) 2 . Hydrogen atoms have been omitted for clarity. Key: InSe ${ }_{4}$, blue tetrahedra; carbon, small green circles; nitrogen, small blue circles.

(a)

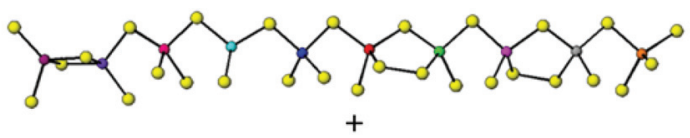

(b)

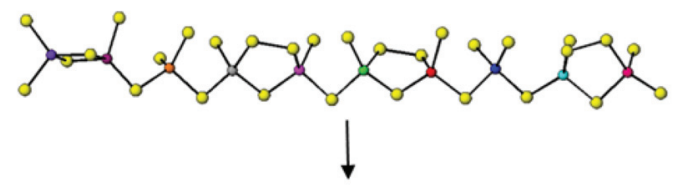

(c)

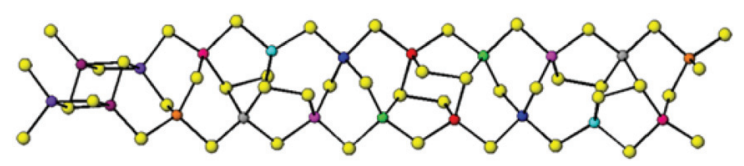

Fig. 4 Two one-dimensional chains of $\operatorname{lnSe_{4}}$ tetrahedra (a) and (b) fuse in (c) to form the $\left[\ln _{10} \mathrm{Se}_{15}\left(\mathrm{Se}_{2}\right)_{3}\right]^{6-}$ ribbon found in 3. Each crystallographically independent indium atom along the chain is shown in a different colour, and selenium is shown in yellow.

range from $2.411(2)$ to $2.438(2) \AA$, which are slightly longer than those reported for $\left(\mathrm{Se}_{2}\right)^{2-}$ units in other indium selenides, ${ }^{12}$ but within the range of Se-Se distances observed in polyselenides. ${ }^{19}$

The $\left[\operatorname{In}_{10} \mathrm{Se}_{15}\left(\mathrm{Se}_{2}\right)_{3}\right]^{6-}$ ribbons in 3 can be described as consisting of two identical one-dimensional chains of $\mathrm{InSe}_{4}$ tetrahedra, related by a rotation of $180^{\circ}$, and fused to form a ribbon (Fig. 4). This ribbon exhibits twists where the tetrahedra are connected via edge-sharing linkages (Fig. 5). In the crystal structure of 3 , the ribbons are aligned parallel to the [101] direction and interspaced by DABCO moieties, which surround the ribbons. At each twist in the ribbon, the DABCO moiety is rotated by $\sim 90^{\circ}$ with respect to the other DABCO molecules. This may be related to the presence of hydrogen- 


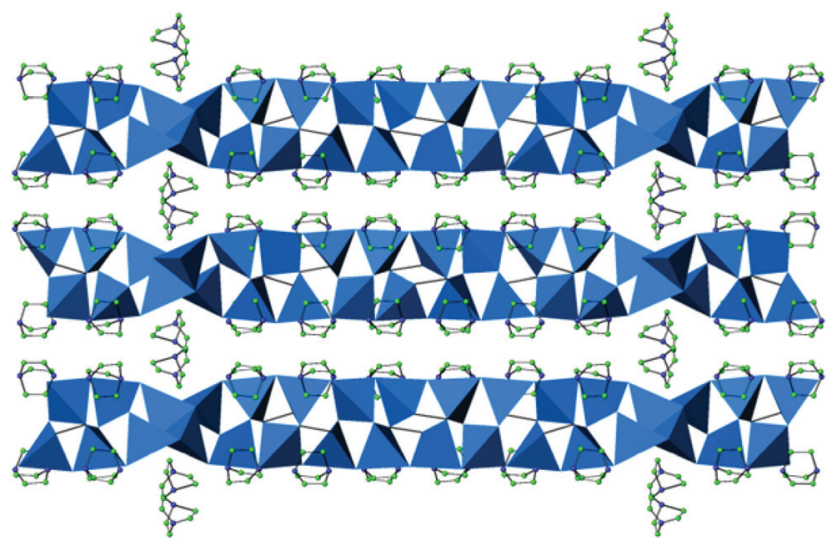

Fig. 5 Polyhedral representation of the crystal structure of 3 along [001]. Key as for Fig. 3.

bonding interactions between the amine located at the twist and the ribbon, given the N...Se distance of 3.27(3) $\AA$, which is similar in magnitude to previously reported hydrogen-bonding interactions in selenides. ${ }^{6,12 a, 20}$ Charge balance requires protonation of some of the organic molecules, but the structural study is unable to establish directly the degree of protonation of the amines. Given the significantly shorter N...Se distance (3.27(3) $\AA$ ) found for the DABCO at the twist when compared to the remaining crystallographically independent amines ( $>4.1 \AA$ ), the former is likely to be protonated. There are also short $\mathrm{N} \cdots \mathrm{N}$ distances ( $c a .2 .7 \AA$ ) between neighbouring DABCO moieties, consistent with $\mathrm{N}-\mathrm{H} \cdots \mathrm{N}$ bonding interactions.

\section{Crystal structure of 4}

Compound 4 is the first example of incorporation of a sodium complex into a solvothermally-prepared indium selenide. The crystal structure of this material contains one-dimensional ribbons, linked into a three-dimensional structure by $\left[\mathrm{NaSe}_{3}-\right.$ $\left.(\mathrm{DABCO})_{2}\right]^{5-}$ complexes. In 4, edge and corner linkages between $\mathrm{InSe}_{4}{ }^{5-}$ tetrahedra result in the formation of a onedimensional ribbon, with stoichiometry $\left[\mathrm{In}_{5} \mathrm{Se}_{9}\right]^{3-}$. This ribbon is closely related to those found in $\mathbf{1}$ and $\mathbf{2}$, although in this case, no perselenide $\left(\mathrm{Se}_{2}\right)^{2-}$ anions are present (Fig. 2(b)).

The ribbons are oriented along the [101] direction and linked into a three-dimensional network (Fig. 6(a)) by trigonal bipyramidal complexes of $\left[\mathrm{NaSe}_{3}(\mathrm{DABCO})_{2}\right]^{5-}$. In this complex, sodium is bonded to three selenium atoms from three neighbouring ribbons, in the equatorial positions and two nitrogen atoms from two DABCO molecules, in the axial positions (Fig. 6(b)). The Na-Se distances are 2.9681(13) and 2.973(3) ^, comparable to those in $\mathrm{Na}_{2} \mathrm{Se}_{2},{ }^{21}$ and the Na-N distance is 2.516(3) ̊, longer than the $\mathrm{Na}-\mathrm{N}$ bonds in $\mathrm{Na}_{3} \mathrm{~N}^{22}$ This might be a consequence of steric interactions between the ligands. This sodium complex is extremely unusual. The closest precedent is found in a small number of thiolates in which sodium is coordinated to $\mathrm{N}$ and $\mathrm{S}$ atoms with a coordination number of 5 , but their geometry is better described as that of a distorted square planar pyramid. ${ }^{23}$ To the best of our knowledge, examples containing selenium are not known. (a)

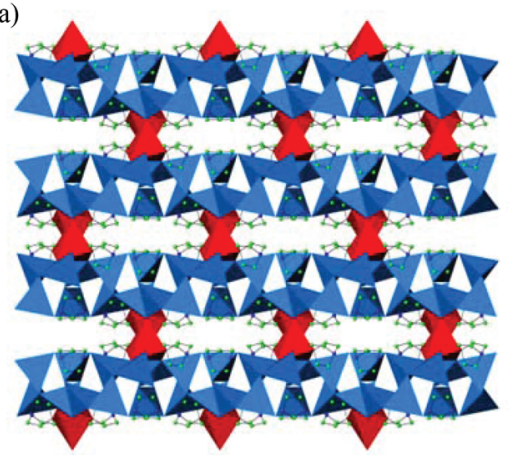

(b)

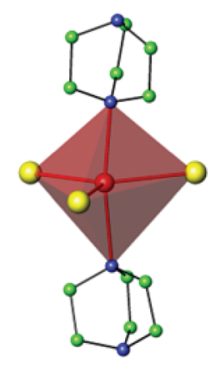

Fig. 6 Polyhedral representation of (a) the crystal structure of 4 along the [001] direction, and (b) the $\left[\mathrm{NaSe}_{3}(\mathrm{DABCO})_{2}\right]^{5-}$ complex. Key: $\operatorname{lnSe}{ }_{4}$, blue tetrahedra; $\mathrm{NaSe}_{3} \mathrm{~N}_{2}$, red bipyramid; carbon, small green circles; nitrogen, small blue circles.

To achieve charge balance, one diprotonated DABCO cation per formula unit is incorporated into the structure of 4 . There are relatively short $\mathrm{N} \cdots \mathrm{N}$ distances between the DABCO cations and the $\left[\mathrm{NaSe}_{3}(\mathrm{DABCO})_{2}\right]^{5-}$ complexes, of 2.705(5) $\AA$, which imply the presence of hydrogen-bonding interactions. Although 4 exhibits a three-dimensional structure, when van der Waals' radii are taken into account there is no available porosity or free channels. This material hence consists of a dense framework.

\section{Crystal structure of 5}

Compound 5 is a rare example of a three-dimensional indium selenide. The asymmetric unit of 5 (ESI) contains seven crystallographically-independent indium atoms, all of which are tetrahedrally coordinated to selenium. The simplest secondary building block in 5 is shown in Fig. 7(a). In this unit, tetrahedra containing $\operatorname{In}(2), \operatorname{In}(4)$ and $\operatorname{In}(5)$ are corner-linked forming a chain. This is linked to another chain of corner-linked tetrahedra containing $\operatorname{In}(3), \operatorname{In}(6)$ and $\operatorname{In}(7)$. The $\operatorname{In}(1) \mathrm{Se}_{4}$ tetrahedron caps this double chain by corner-linking to $\operatorname{In}(2), \operatorname{In}(3)$ and $\operatorname{In}(7) \mathrm{Se}_{4}$ tetrahedra. These units of seven tetrahedra are linked into two-dimensional buckled layers (Fig. 7(b)) by the terminal Se vertices. Rotation by $90^{\circ}$ of the layers depicted in Fig. 7(b), followed by their linkage through the corner of the capping tetrahedron, $\left(\operatorname{In}(1) \mathrm{Se}_{4}\right)$, results in the formation a three-dimensional framework, illustrated in Fig. 7(c).

For this anionic framework, the solvent accessible void space, calculated using the SOLV function in PLATON ${ }^{24}$ is only $18.9 \%$ of the unit cell volume. This void space consists of small cavities where protonated ethylenediamine and ammonium cations reside. There is a number of N...Se distances indicative of hydrogen-bonding interactions between the framework and the organic moieties. Each of the $-\mathrm{NH}_{3}{ }^{+}$ groups of the $\mathrm{enH}_{2}{ }^{2+}$ cation are involved in three $\mathrm{H}$-bonding interactions with distances in the range 3.35(2) to 3.57(3) $\AA$, with the $\mathrm{NH}_{4}{ }^{+}$cation involved in four $\mathrm{N}-\mathrm{H} \cdots$ Se interactions of 3.34(1) to 3.59(1) $\AA$ which are comparable to interactions in previously reported indium and gallium selenides. ${ }^{6,12 a, 20}$ 
(a)
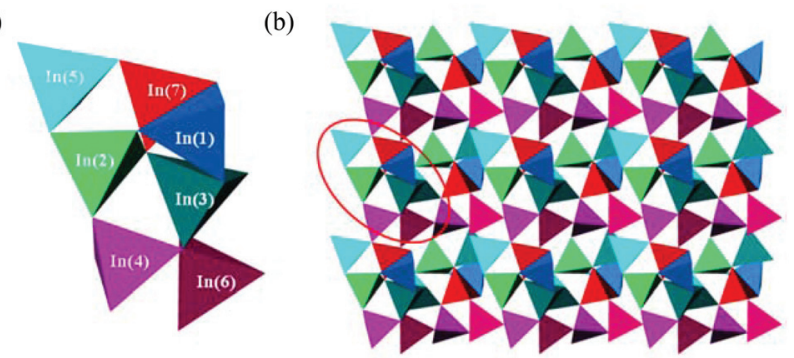

(c)

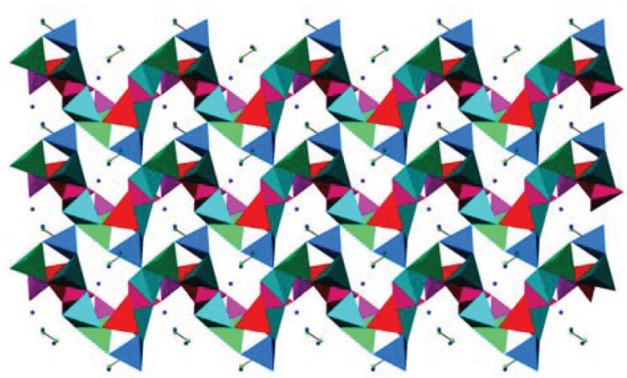

Fig. 7 Polyhedral representation of (a) the secondary building block in 5; (b) the zig-zag layer in 5, with the secondary building block circled, and (c) view of the crystal structure of 5 along the [100] direction. Key: $\ln (1) \mathrm{Se}_{4}$, blue; $\ln (2) \mathrm{Se}_{4}$, green; $\ln (3) \mathrm{Se}_{4}$, teal; $\ln (4) \mathrm{Se}_{4}$, purple; $\ln (5) \mathrm{Se}_{4}$, turquoise; $\ln (6) \mathrm{Se}_{4}$, pink; $\ln (7) \mathrm{Se}_{4}$, red; carbon, small green circles; nitrogen, small blue circles. Hydrogen atoms have been omitted for clarity.

\section{Characterisation}

Powder X-ray diffraction data (ESI) collected on the bulk products of the reactions producing 1-5 indicate that 1-5 are the main products of the reactions, and the lattice parameters (ESI) determined for 1-5 using powder X-ray diffraction data are in good agreement with those determined by single-crystal diffraction.

Thermogravimetric analysis (ESI) was carried out on handpicked crystals of 1-5 under an oxidizing atmosphere. Compounds were found to be stable up to $180-250{ }^{\circ} \mathrm{C}$. The weight loss occurs as a multistage process, with the overall weight change corresponding to the decomposition of the starting material into $\mathrm{In}_{2} \mathrm{O}_{3}$. For 1, 3 and 5, a small increase in weight is observed between 300 and $400{ }^{\circ} \mathrm{C}$, suggesting that a selenate, selenite or oxyselenide may form in the initial stages of the decomposition process. The found weight losses, together with those calculated for the removal of the amine are as follows: 1 found: $61.2 \%$; calc.: $61.8 \% ; 2$ found: $62.2 \%$; calc.: $60.7 \%$; 3 found: $59.8 \%$; calc.: $61.5 \% ; 4$ found: $57.2 \%$; calc.: $57.8 \%$; 5 found: $48.3 \%$; calc.: $46.9 \%$.

FT-IR data (ESI) collected for $\mathbf{1}$ to $\mathbf{5}$ show bands consistent with the organic species identified within the structure by X-ray crystallography. Bands observed for $\mathbf{1}$ and 2 are consistent with the presence of $\mathrm{DBUH}^{+}$. For instance, the strong bands at 1685 to $1580 \mathrm{~cm}^{-1}$ correspond to the $\mathrm{C}-\mathrm{N}$ stretch, that at $\sim 2900 \mathrm{~cm}^{-1}$ can be assigned to $\mathrm{C}-\mathrm{H}$ stretches, whilst the bands at 1632 and $1443 \mathrm{~cm}^{-1}$ are characteristic of $\nu(\mathrm{C}=\mathrm{N})$ and $\delta(\mathrm{C}-\mathrm{H})$ respectively. Bands at lower wavenumbers (1320 to $1000 \mathrm{~cm}^{-1}$ ) are consistent with deformation and bends of $\mathrm{C}-\mathrm{N}$ and $\mathrm{C}-\mathrm{C}$ bonds. Bands in $\mathbf{3}$ and $\mathbf{4}$ are consistent with the presence of protonated and unprotonated DABCO, as established by comparison with the assignments reported by Guzonas and Irish. ${ }^{25}$ FT-IR data for $\mathbf{5}$ are consistent with the presence of the $\left[\mathrm{NH}_{4}\right]^{+}$cation within the crystal structure. The band at $\sim 3000 \mathrm{~cm}^{-1}$ can be assigned to the $\mathrm{N}-\mathrm{H}$ symmetric stretching vibration, with the signal at $1600 \mathrm{~cm}^{-1}$ corresponding to $\mathrm{N}-\mathrm{H}$ deformation of the $\left[\mathrm{NH}_{4}\right]^{+}$cations. The signal $1400 \mathrm{~cm}^{-1}$ can be assigned to an $\mathrm{N}-\mathrm{H}$ bending mode. ${ }^{26}$ Other peaks in the spectra are consistent with the presence of protonated ethylenediamine within the crystal structure $\left(\sim 1524 \mathrm{~cm}^{-1}-\mathrm{N}-\mathrm{H}\right.$ def, $\left.1478 \mathrm{~cm}^{-1} \nu \mathrm{C}-\mathrm{N}\right)$.

\section{Optical absorption properties}

UV-Vis diffuse reflectance measurements (Fig. 8) were carried out to estimate the optical band gap of compounds 1-5. The band gap values, which are given in Table 2, are consistent with the colour of the crystals (Fig. 8). For antimony sulphides, the band gap variation has been related to the density of metal
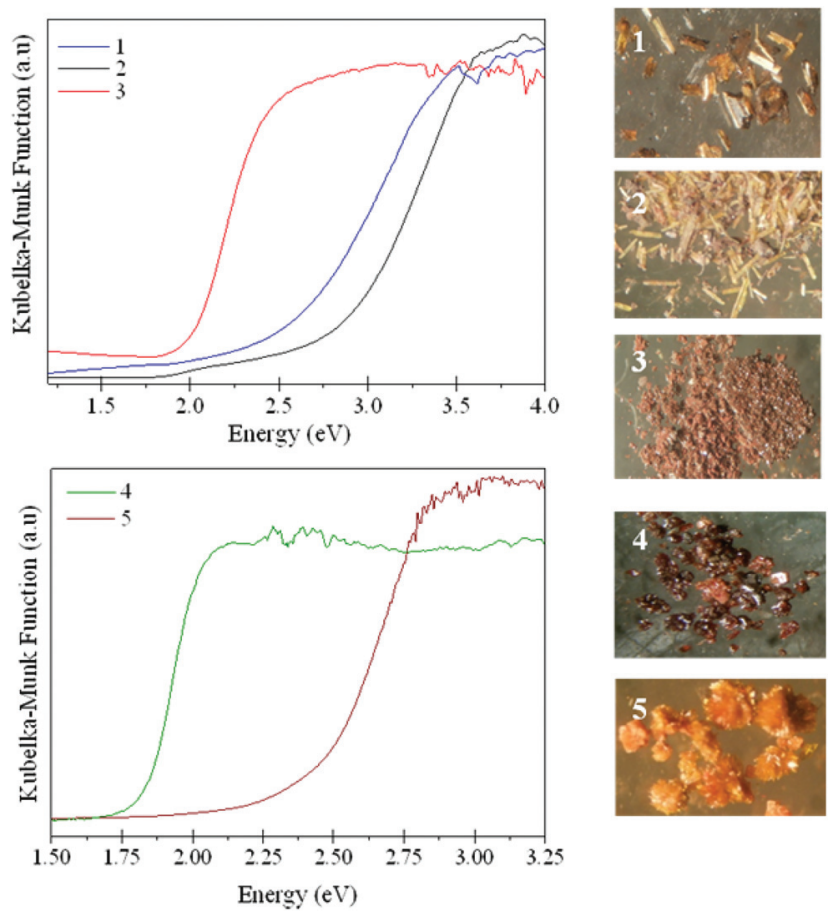

Fig. 8 UV-Vis diffuse reflectance spectra for (a) compounds 1-3 and (b) 4 and 5 (left). Photographs of the crystals of 1-5 (right).

Table 2 Optical band gap and density of metal centres for compounds 1-5

\begin{tabular}{lll}
\hline Compound & Band gap/eV & In atoms per $1000\left(\AA^{3}\right)$ \\
\hline $\mathbf{1}$ & $2.49(3)$ & 4.3 \\
$\mathbf{2}$ & $2.83(4)$ & 4.5 \\
$\mathbf{3}$ & $1.88(3)$ & 4.9 \\
$\mathbf{4}$ & $1.79(1)$ & 5.4 \\
$\mathbf{5}$ & $2.44(2)$ & 9.6
\end{tabular}


centres within the crystal structures. ${ }^{27}$ This correlation has been attributed to the weakening of the interactions between anion and cation orbitals with decreasing density, which has an effect on the energy levels at the top of the valence band. As shown in Table 2, this simple relationship between band gap and density of metal centres (given as number of In atoms per $1000 \AA^{3}$ ) does not hold here. We have previously observed, when comparing the related chains $\left[\mathrm{GaSe}_{2}\right]^{-}$and $\left[\mathrm{Ga}_{2} \mathrm{Se}_{3}\left(\mathrm{Se}_{2}\right)\right]^{2-}$, a marked reduction of the band gap when $\left(\mathrm{Se}_{2}\right)^{2-}$ anions are present. ${ }^{28}$ Similarly, the band gap of $[\mathrm{DBUH}]_{2}\left[\mathrm{Hg}_{2} \mathrm{Sn}_{2} \mathrm{Se}_{6}\left(\mathrm{Se}_{2}\right)\right]$ is lower than that of the closely related $[\mathrm{DBUH}]_{2}\left[\mathrm{Hg}_{2} \mathrm{Sn}_{2} \mathrm{Se}_{7}\right]{ }^{29}$ This suggests that the perselenide anion contributes to energy levels close to the band gap, and hence may explain the larger band gap found for $\mathbf{5}$, when compared to those of the materials containing perselenides (1-3). The band gap variation between $\mathbf{4}$ and $\mathbf{5}$ does not follow either the expected trend of a smaller band gap with increasing framework density. This is perhaps not surprising, given that in these materials the connectivity between tetrahedra is very different and they also differ in the presence of Na.

\section{Discussion}

\section{Synthetic considerations}

The preparation, under mild solvothermal conditions, of compounds containing sulfur-sulfur bonds occurs only rarely. Despite the large number of main-group sulfides prepared by solvothermal synthesis, ${ }^{30}$ examples containing $\mathrm{S}-\mathrm{S}$ bonds remain scarce. ${ }^{31}$ By contrast, recent literature provides growing evidence of the relative ease of formation of compounds containing Se-Se bonds under solvothermal conditions. For example, $\left(\mathrm{Se}_{n}\right)^{2-}$ anions have been found in a variety of chains, including $\left[\mathrm{M}_{2} \mathrm{Se}_{3}\left(\mathrm{Se}_{2}\right)\right]^{2-}(\mathrm{M}=\mathrm{Ga}, \mathrm{In}),\left[\mathrm{Ga}_{2} \mathrm{Se}_{2}\left(\mathrm{Se}_{2}\right)\left(\mathrm{Se}_{3}\right)\right]^{2-}$ and $\left[\mathrm{Ga}_{2} \mathrm{Se}_{2}\left(\mathrm{Se}_{2}\right)_{2}\right]^{2-12,20,28}$ and in heterometallic ribbons such as $[\mathrm{DBUH}]_{2}\left[\mathrm{Hg}_{2} \mathrm{Sn}_{2} \mathrm{Se}_{6}\left(\mathrm{Se}_{2}\right)\right]$ and $[\mathrm{DBNH}]_{4}\left[\mathrm{Cd}_{3} \mathrm{Sn}_{4} \mathrm{Se}_{11}\left(\mathrm{Se}_{2}\right)_{2}\right]$ (where DBN $=1,5$-diazabicyclo[4.3.0]non-5-ene), ${ }^{29,32}$ as well as the compounds 1-3 reported here. This contrasting behaviour may be related to the greater tendency shown by the heavier chalcogens to form chalcogen-rich phases, containing chalcogen-chalcogen bonds. Examination of the synthetic conditions suggests that the preparation of phases containing $\left(\mathrm{Se}_{n}\right)^{2-}$ occurs more readily when more basic amines are used as solvents and/or structure-directing agents. For instance, we have observed that reactions using substituted pyridines as solvents, with $\mathrm{p} K_{\mathrm{a}}$ values of $\sim 5$ to 7 , have resulted in materials that do not contain perselenides, ${ }^{6,10}$ while reactions using primary amines (e.g. 1,4-diaminobutane, $\left.\mathrm{p} K_{\mathrm{a}} \sim 10.8\right)^{33}$ or amidines, which are strongly basic, have produced perselenides..$^{20,28,32}$ of the amines used here, DBU $\left(\mathrm{p} K_{\mathrm{a}} \sim 24.3\right)^{34}$ is more strongly basic than DABCO $\left(\mathrm{p} K_{\mathrm{a}} \sim 8.9\right),{ }^{35}$ which has a $\mathrm{p} K_{\mathrm{a}}$ comparable to that of some alkyl amines. In both cases, materials containing $\left(\mathrm{Se}_{2}\right)^{2-}$ have been obtained. Potential/pH diagrams for selenium in aqueous solutions at ambient conditions indicate that polyselenides are predominant species at high values of $\mathrm{pH}{ }^{36} \mathrm{~A}$ similar trend seems to occur under solvothermal con-

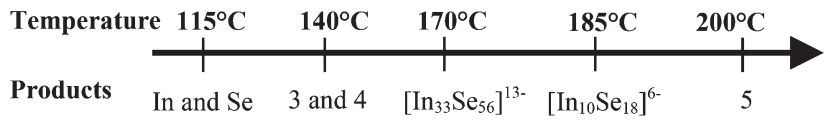

Scheme 1 Products obtained at different temperatures when using $\mathrm{DABCO}$ as a structure-directing agent.

ditions. Further experimental data on selenides synthesised using different structure-directing agents will be useful to confirm the relationship between $\mathrm{p} K_{\mathrm{a}}$ and the presence of $\left(\mathrm{Se}_{2}\right)^{2-}$ anions.

With DBU as a structure-directing agent, compounds $\mathbf{1}$ and 2, which differ in their $\left(\mathrm{Se}_{2}\right)^{2-}$ content, were obtained by varying the indium source and solvent, as well as adding imidazole, which is not incorporated in the final crystal structure. This suggests that other reaction parameters can influence the amount of $\left(\mathrm{Se}_{2}\right)^{2-}$ anions incorporated into the crystal structure. It has been previously shown that the one-dimensional [DBUH $]_{2}\left[\mathrm{Hg}_{2} \mathrm{Sn}_{2} \mathrm{Se}_{6}\left(\mathrm{Se}_{2}\right)\right]$ transforms into [DBUH $]_{2}\left[\mathrm{Hg}_{2} \mathrm{Sn}_{2} \mathrm{Se}_{7}\right]$ when increasing the reaction time. ${ }^{29}$ Attempts to control the $\left(\mathrm{Se}_{2}\right)^{2-}$ content in the $\left[\mathrm{In}_{5} \mathrm{Se}_{8+x}\left(\mathrm{Se}_{2}\right)_{1-x}\right]^{3-}$ ribbons by varying the time were carried out, but these have not been successful so far. While DBU was found to be stable at the reaction temperatures investigated $\left(115-200{ }^{\circ} \mathrm{C}\right)$, DABCO only remained intact when low reaction temperatures were used. It was found that reactions using DABCO afforded a variety of structures of differing dimensionality, including the previously reported frameworks $\left[\operatorname{In}_{33} \mathrm{Se}_{56}\right]^{13-}$ and $\left[\operatorname{In}_{10} \mathrm{Se}_{18}\right]^{6-}$, 7,9 which were obtained at 170 and $185{ }^{\circ} \mathrm{C}$ respectively (see ESI $\dagger$ ). A summary of the compounds obtained using DABCO is given in Scheme 1. As the temperature of the reaction is raised, an increase in the dimensionality of the products, together with an increase in the density of metal centres, is observed. At $140{ }^{\circ} \mathrm{C}$, the materials prepared, 3 and 4 , contain one-dimensional ribbons, while at intermediate temperatures, the microporous frameworks $\left[\mathrm{In}_{33} \mathrm{Se}_{56}\right]^{13-}$ and $\left[\mathrm{In}_{10} \mathrm{Se}_{18}\right]^{6-}$, both of which have a porosity of $c a .50 \%$ of the available unit cell volume, ${ }^{7,9}$ are obtained. Compound $\mathbf{5}$, which was prepared at the highest temperature investigated, $200{ }^{\circ} \mathrm{C}$, consists of a dense three-dimensional framework with no accessible porosity. Similar findings have been reported for the solvothermal synthesis of cobalt succinates and for hybrid vanadium oxyfluorides, where increased condensation and density was found as reaction temperatures increased. ${ }^{37}$ Although there are no systematic studies on the effect of temperature on the solvothermal synthesis of indium selenides, similar results have been found for other metal chalcogenides. In particular, the solvothermal synthesis, in the presence of ethylenediamine, of antimony sulfides containing transition-metal complexes has been extensively explored. ${ }^{38}$ In this system, it has been shown that a change of only $25^{\circ} \mathrm{C}$ can result in the condensation of isolated $\left[\mathrm{Sb}_{2} \mathrm{~S}_{5}\right]^{2-}$ anions into $\left[\mathrm{SbS}_{2}\right]^{-}$chains, ${ }^{38 a}$ although changes in reagent concentration whilst maintaining a constant temperature can also result in markedly different products. ${ }^{38 b}$ Similarly, for tin chalcogenides, marked changes in the structure dimensionality have been achieved at room 
temperature by varying the reactants and solvent concentrations. $^{39}$

\section{Structural chemistry}

The anionic ribbons found in 1-4 are the first examples of ribbons in indium selenides. Two distinct ribbons, both of which constitute new structural types, have been identified in this work. Compounds 1, 2 and 4 contain anionic ribbons with the general formula $\left[\operatorname{In}_{5} \mathrm{Se}_{8+x}\left(\mathrm{Se}_{2}\right)_{1-x}\right]^{3-}$, while 3 contains a $\left[\mathrm{In}_{10} \mathrm{Se}_{15}\left(\mathrm{Se}_{2}\right)_{3}\right]^{6-}$ ribbon. In both cases, corner- and edgesharing linkages of $\operatorname{InSe}_{4}{ }^{5-}$ tetrahedra coexist in the ribbon, and this can lead to a long repeating sequence along the ribbon, as found in 3, where the distances between consecutive twists is $c a .36 \AA$. In the case of the $\left[\operatorname{In}_{5} \mathrm{Se}_{8+x}\left(\mathrm{Se}_{2}\right)_{1-x}\right]^{3-}$ ribbons, partial substitution of $\mathrm{Se}^{2-}$ with $\left(\mathrm{Se}_{2}\right)^{2-}$ occurs in the $\left[\mathrm{In}_{2} \mathrm{Se}_{2}\right]$ rings in $\mathbf{1}$ and $\mathbf{2}$, whilst 4 contains no perselenide. Although the complete replacement of $\mathrm{Se}^{2-}$ with a perselenide has been observed in simple indium selenide chains, ${ }^{12}$ partial substitution had not been previously encountered. The existence of ribbons with $x$ values of $0,0.26$ and 0.93 suggests that the synthesis of analogous ribbons with different perselenide contents should be possible, and this could be exploited to control the properties (e.g. optical band gap) of these materials. Although there are no prior reports of indium selenide ribbons in the literature, anionic ribbons, with entirely different structural motifs to the compounds described here, have been found in the tin selenides $[\mathrm{DBUH}]_{2}\left[\mathrm{Hg}_{2} \mathrm{Sn}_{2} \mathrm{Se}_{6}\left(\mathrm{Se}_{2}\right)\right]$ and $[\mathrm{DBUH}]_{2}\left[\mathrm{Hg}_{2} \mathrm{Sn}_{2} \mathrm{Se}_{7}\right]^{29}$ as well as in the tellurides $[\mathrm{HTMDP}]_{2}\left[\mathrm{In}_{4} \mathrm{Te}_{8}\right]$ and $[\mathrm{HDAP}]_{8}\left[\mathrm{In}_{12} \mathrm{Te}_{23}\right]$ (where TMDP $=4,4^{\prime}-$ trimethylenedipiperidine and DAP $=1,3$,-diaminopropane). ${ }^{40}$ The mercury tin selenides differ from the ribbons reported here in the absence of edge linkages between tetrahedra, while in the indium tellurides, a combination of corner- and edgesharing also occur. Whilst [HTMDP $]_{2}\left[\mathrm{In}_{4} \mathrm{Te}_{8}\right]$ does not contain $\left(\mathrm{Te}_{2}\right)^{2-}$ units, the structure of $[\mathrm{HDAP}]_{8}\left[\mathrm{In}_{12} \mathrm{Te}_{23}\right]$ consists of helical double chains of $\mathrm{InTe}_{4}{ }^{5-}$ tetrahedra connected into a 3-dimensional network by $\left[\mathrm{In}_{2} \mathrm{Te}_{3}\right]$ rings which contain a $\left(\mathrm{Te}_{2}\right)^{2-}$ anion. ${ }^{40}$

In compound 4 , the indium selenide ribbons are linked into a 3-dimensional network by highly unusual $\left[\mathrm{Na}(\mathrm{DABCO})_{2}\right]^{+}$units. While $\mathrm{Na}^{+}$ions can act as countercations, as exemplified by the indium selenide framework ICF- $21,{ }^{2}$ the incorporation of an alkali-metal complex as a bridging unit into a solvothermally-prepared chalcogenide is unprecedented. Transition-metal complexes have been shown to act as countercations, pendants groups or linkers. ${ }^{41}$ By contrast, there are very few known examples of chalcogenides containing complexes of group 1 and 2 elements. These appear to be limited to the $\left[\mathrm{Mg}(\mathrm{en})_{3}\right]^{2+}$ complexes, which act as countercations in $\left[\mathrm{Mg}(\mathrm{en})_{3}\right]\left[\mathrm{Sb}_{4} \mathrm{~S}_{7}\right]$ and $\left[\mathrm{Mg}(\mathrm{en})_{3}\right]\left[\mathrm{In}_{2} \mathrm{~S}_{4}\right],{ }^{42}$ and the $\left[\mathrm{Na}_{5}\left(\mathrm{H}_{2} \mathrm{O}\right)_{6}\right]^{5+}$ clusters, which fill the cavities in the 3-dimensional frameworks of $\mathrm{Na}_{5}\left(\mathrm{M}_{4} \mathrm{~S}\right)\left(\mathrm{MS}_{4}\right)_{3} \cdot 6 \mathrm{H}_{2} \mathrm{O}\left(\mathrm{M}=\mathrm{Ga}\right.$, In). ${ }^{43}$ Compound $\mathbf{5}$ also exhibits a three-dimensional structure, which arises from corner linkage of $\mathrm{InSe}_{4}{ }^{5-}$ tetrahedra. Only a small number of indium selenide frameworks are known, ${ }^{2,3,7,9,10}$ and $\mathbf{5}$ differs from previously reported examples in its lack of channels or accessible porosity. This material, which is obtained at temperatures at which DABCO decomposes, consists of a highly dense framework, containing only small cavities.

\section{Conclusions}

We have demonstrated that bicyclic amines can be used for the preparation of complex indium selenides, containing perselenide $\left(\mathrm{Se}_{2}\right)^{2-}$ anions, and identified amine $\mathrm{p} K_{\mathrm{a}}$ as a significant parameter for the targeted synthesis of perselenides. In addition, the thermal stability of the amine under solvothermal conditions is important in order to produce new structural types. We have also shown that alkali-metal complexes can act as linkages in indium selenide frameworks, and identified a range of entirely new structural building blocks in these materials. These findings indicate that a wide range of complex indium selenides, containing $\left(\mathrm{Se}_{n}\right)^{2-}$ anions and/or alkali-metal complexes, should be accessible through mild solvothermal reactions.

\section{Acknowledgements}

SJE would like to thank Heriot-Watt University for a studentship. The authors would like to thank Christina Graham for elemental analysis data.

\section{Notes and references}

1 (a) N. Zheng, X. Bu, H. Vu and P. Feng, Angew. Chem., Int. Ed., 2005, 44, 5299; (b) Z. Zhang, J. Zhang, T. Wu, X. Bu and P. Feng, J. Am. Chem. Soc., 2008, 130, 15238.

2 N. Zheng, X. Bu and P. Feng, Nature, 2003, 426, 428.

3 M. J. Manos, C. D. Malliakas and M. G. Kanatzidis, Chem. Eur. J., 2007, 13, 51.

4 Q. Zhang, I. Chung, J. I. Jang, J. B. Ketterson and M. G. Kanatzidis, Chem. Mater., 2009, 21, 12.

5 (a) P. Feng, X. Bu and N. Zheng, Acc. Chem. Res., 2005, 38, 293; (b) X. Bu, N. Zheng and P. Feng, Chem. - Eur. J., 2004, 10, 3356; (c) L. Wang, T. Wu, X. Bu, X. Zhao, F. Zuo and P. Feng, Inorg. Chem., 2013, 52, 2259; (d) T. Wu, X. Bu, P. Liao, L. Wang, S.-T. Zheng, R. Ma and P. Feng, J. Am. Chem. Soc., 2012, 134, 3619; (e) T. Wu, F. Zuo, L. Wang, X. Bu, S.-T. Zheng, R. Ma and P. Feng, J. Am. Chem. Soc., 2011, 133, 15886.

6 S. J. Ewing, A. V. Powell and P. Vaqueiro, Inorg. Chem., 2012, 51, 7404.

7 C. Wang, X. Bu, N. Zheng and P. Feng, Chem. Commun., 2002, 1344.

8 S. J. Ewing, D. I. Woodward, A. V. Powell and P. Vaqueiro, J. Solid State Chem., 2013, 204, 159.

9 C. Wang, X. Bu, N. Zheng and P. Feng, Angew. Chem., Int. Ed., 2002, 41, 1959.

10 P. Vaqueiro, Inorg. Chem., 2008, 47, 20. 
11 K.-Z. Du, W.-B. Hu, B. Hu, X.-F. Guan and X.-Y. Huang, Mater. Res. Bull., 2011, 46, 1969.

12 (a) S. J. Ewing, A. V. Powell and P. Vaqueiro, J. Solid State Chem., 2011, 184, 1800; (b) X. Zhang, Z.-X. Lei, W. Luo, W.-Q. Mu, X. Zhang, Q.-Y. Zhu and J. Dai, Inorg. Chem., 2011, 50, 10872; (c) H. G. Yao, M. Ji, S.-H. Ji and Y. L. An, Z. Anorg. Allg. Chem., 2012, 638, 683.

13 C. L. Cahill and P. C. Burns, Inorg. Chem., 2001, 40, 1347.

14 L. Palatinus and G. Chapuis, J. Appl. Crystallogr., 2007, 40, 786.

15 G. M. Sheldrick, Acta Crystallogr., Sect. A: Fundam. Crystallogr., 2008, 64, 112.

16 P. W. Betteridge, J. R. Carruthers, R. I. Cooper, K. Prout and D. J. Watkin, J. Appl. Crystallogr., 2003, 36, 1487.

17 TOPAS, Version 3, Bruker-AXS Inc, Madison, Wisconsin, USA, 1999.

18 W. W. Wendlandt and H. G. Hecht, Reflectance Spectroscopy, Interscience publishers, New York, 1966.

19 W. S. Sheldrick and H. G. Braunbeck, Z. Naturforsch., B: Chem. Sci., 1989, 44, 1397.

20 W.-W. Xiong, J.-R. Li, M.-L. Feng and X.-Y. Huang, CrystEngComm, 2011, 13, 6206.

21 H. Foeppl, E. Busmann and F. K. Frorath, Z. Anorg. Allg. Chem., 1962, 314, 12.

22 D. Fischer and M. Jansen, Angew. Chem., Int. Ed., 2002, 41, 1755.

23 (a) S. Chadwick and K. Ruhlandt-Senge, Chem. - Eur. J., 1998, 4, 1768; (b) U. Englich and K. Ruhlandt-Senge, Coord. Chem. Rev., 2000, 210, 135.

24 A. L. Spek, J. Appl. Crystallogr., 2003, 36, 7.

25 D. A. Guzonas and D. E. Irish, Can. J. Chem., 1988, 66, 1249.

26 K. Nakamoto, Infrared and Raman Spectra of Inorganic and Coordination Compounds, Part A, Wiley Interscience Publication, USA, 5th edn, 1997, p. 189.

27 A. V. Powell, R. J. E. Lees and A. M. Chippindale, J. Phys.: Chem. Solids, 2008, 69, 1000.

28 S. J. Ewing, M. L. Romero, J. Hutchinson, A. V. Powell and P. Vaqueiro, Z. Anorg. Allg. Chem., 2012, 638, 2526.

29 W.-W. Xiong, P.-Z. Li, T.-H. Zhou, A. I. Y. Tok, R. Xu, Y. Zhao and Q. Zhang, Inorg. Chem., 2013, 52, 4148.

30 (a) W. S. Sheldrick and M. Wachhold, Coord. Chem. Rev., 1998, 176, 211; (b) A. V. Powell, Int. J. Nanotechnol., 2011, 8, 783.

31 (a) P. Vaqueiro and M. L. Romero, J. Phys. Chem. Solids, 2007, 68, 1239; (b) N. Zheng, X. Bu and P. Feng, J. Am. Chem. Soc., 2003, 125, 1138; (c) Y.-H. Wang, J.-B. Jiang, P. Wang, X.-L. Sun, Q.-Y. Zhu and J. Dai, CrystEngComm,
2013, 15, 6040; (d) K. M. Tan, Y. H. Ko, J. B. Parise, J. H. Park and A. Darovsky, Chem. Mater., 1996, 8, 2510.

32 W.-W. Xiong, K. Ye, L. Ye and Q. Zhang, Inorg. Chem. Commun., 2013, 35, 337.

33 CRC Handbook of Chemistry and Physics, CRC Press, New York, 74th edn, 2003.

34 E.-I. Room, A. Kütt, I. Kaljurand, I. Koppel, I. Leito, I. A. Koppel, M. Mishima, K. Goto and M. Miyahara, Chem. - Eur. J., 2007, 13, 7631.

35 R. L. Benoit, D. Lefebvre and M. Frechette, Can. J. Chem., 1987, 65, 996.

36 A. Olin, B. Nolang, E. G. Osadchii, L.-O. Ohman and E. Rosen, in Chemical Thermodynamics Series: Chemical Thermodynamics of Selenium, ed. F. J. Mompean, J. Perrone and M. Illemassene, OECD Nuclear Energy Agency Data Bank, 2005, vol. 7, pp. 158-160.

37 (a) P. M. Forster, A. R. Burbank, C. Livage, G. Férey and A. K. Cheetham, Chem. Commun., 2004, 368; (b) D. W. Aldous, N. F. Stephens and P. Lightfoot, Dalton Trans., 2007, 4207.

38 (a) R. J. E. Lees, A. V. Powell and A. M. Chippindale, Polyhedron, 2005, 24, 1941; (b) H.-O. Stephan and M. G. Kanatzidis, Inorg. Chem., 1997, 36, 6050; (c) R. J. E. Lees, A. V. Powell and A. M. Chippindale, J. Phys. Chem. Solids, 2007, 68, 1215; (d) P. Vaqueiro, A. M. Chippindale and A. V. Powell, Inorg. Chem., 2004, 43, 7963; (e) L. Engelke, R. Stahler, M. Schur, C. Nather, W. Bensch and R. Pottgen, Z. Naturforsch., B: Chem. Sci., 2004, 59, 869; $(f)$ M. Schur, H. Rijnberk, C. Nather and W. Bensch, Polyhedron, 1998, 18, 101.

39 M. Yuan, M. Dirmyer, J. Badding, A. Sen, M. Dahlberg and P. Schiffer, Inorg. Chem., 2007, 46, 7238.

40 J. Heine, S. Santner and S. Dehnen, Inorg. Chem., 2013, 52, 4424.

41 (a) P. Vaqueiro, Inorg. Chem., 2006, 45, 4150; (b) Y.-H. Wang, M.-H. Zhang, Y.-M. Yan, G.-Q. Bian, Q.-Y. Zhu and J. Dai, Inorg. Chem., 2010, 49, 9731; (c) J. Zhou, J. Dai, G.-Q. Bian and C.-Y. Li, Coord. Chem. Rev., 2009, 253, 1221.

42 (a) E. Quiroga-Gonzalez, C. Näther and W. Bensch, Z. Naturforsh., B: Chem. Sci., 2009, 64, 1312; (b) E. QuirogaGonzalez, L. Kienle, C. Näther, V. S. K. Chakravadhanula, H. Lühmann and W. Bensch, J. Solid State Chem., 2010, 183, 2805.

43 (a) N. Zheng, X. Bu and P. Feng, J. Am. Chem. Soc., 2005, 127, 5286; (b) J. Rumble and P. Vaqueiro, Solid State Sci., 2011, 13, 1137. 